\title{
Analisis Perancangan dan Pengujian Alat Cuci Tangan Otomasis Berbasis Energi Surya 100 WP
}

\author{
Heri Suripto ${ }^{1}$, Unggul Satria Jati ${ }^{2}$ \\ ${ }^{1}$ Program Studi Teknik Teknik Mesin, Universitas Pasir Pengaraian \\ ${ }^{2}$ Program Studi Teknik Mesin, Politeknik Negeri Cilacap \\ Email: $\underline{\text { heri.suriptodotone@gmail.com, }{ }^{2} \text { unggulsatriajati@pnc.ac.id }}$
}

\begin{abstract}
ABSTRAK
Mewabahnya penyakit covid 19 yang menyebabkan bencana bagi masyarakat. Munculnya wabah penyakit ini mendorong pentingnya untuk hidup bersih. Agar tidak mudah tertular penyakit covid 19 maka perlu dibuat alat cuci tangan otomatis untuk menghindari masyarakat kontak langsung dengan alat tersebut. Dalam penelitian ini dilakukan perancangan dan pengujian alat cuci tangan otomastis berbasis energi surya. Tujuan penelitian ini adalah mengetahui kapasitas intensitas matahari untuk memberikan energi listrik melalui modul surya terhadap baterai yang akan digunakan untuk mensuplai energi listrik alat cuci tangan otomatis berbasis energi surya. Metode perancangan yang digunakan dalam penelitian ini adalah pendekatan metode Palh and Beitz dan metode eksperimen yang diawali dengan perancangan, pemilihan material, perakitan dan pengujian. Perancangan menghasilkan spesifikasi alat untuk kerangka modul surya tinggi $100 \mathrm{~cm}$, lebar $80 \mathrm{~cm}$, panjang $100 \mathrm{~cm}$, sedangkan untuk kerangka wastafel memiliki tinggi $90 \mathrm{~cm}$ lebar $45 \mathrm{~cm}$ dan panjang $55 \mathrm{~cm}$. Pengujian dilakukan dengan 3 tahapan, tahap pertama dilakukan pengujian pada daya input modul. Daya input modul pada pengujian menghasilkan daya sebesar 2461 Watt dengan intensitas radiasi matahari sebesar $3237 \mathrm{~W} / \mathrm{m}^{2}$. Puncak intensitas dan daya matahari ditunjukan pada pukul 13.00 WIB. Pengujian ke dua untuk lama waktu pengisian baterai membutuhkan waktu 2,5 jam. Pengujian ketiga yaitu kebutuhan daya sensor dan pompa sebesar 358 Watt. Kebutuhan daya sebesar 358 Watt dapat di suplai oleh panel surya kapasitas $100 \mathrm{Wp}$, karena daya yang dikeluarka dari panel surya $100 \mathrm{Wp}$ sebesar $400 \mathrm{Watt}$.
\end{abstract}

Kata kunci: alat cuci tangan otomatis, energi surya, daya input, intensitas matahari.

\begin{abstract}
The outbreak of the Covid 19 disease has caused disaster to the people. The emergence of this disease's outbreak encourages the importance clean lifestyle. In order not to easily contracted the Covid 19 disease, it is necessary to make automatic handwashing equipment to prevent people from having direct contact with the equipment. In this research the design and testing of an automatic handwashing equipment based on solar energy were carried out. The purpose of this research was to determine the capacity of the sun's intensity to provide electrical energy through the solar module to the battery which will be used to supply electrical energy of solar energy-based automatic handwashing equipment. The method used in this research was the Palh and Beitz method approach and the experimental method which started with the design, material selection, assembly and testing. The design produced equipment specifications for a solar module framework with a height of $100 \mathrm{~cm}$, a width of $80 \mathrm{~cm}, a$ length of $100 \mathrm{~cm}$, while for a sink frame with a height of $90 \mathrm{~cm}$, a width of $45 \mathrm{~cm}$, and a length of $55 \mathrm{~cm}$. The test was carried out in three phases, phase one was testing the module input power. The module input power in the test produced a power of 2461 Watts with a solar radiation intensity of $3237 \mathrm{~W} / \mathrm{m} 2$. The peak intensity and power of the sun was shown at 13.00 WIB. The second phase of the test was the length of time needed to charge the battery took 2.5 hours. The third phase of the test was the power needed for sensors and pumps of 358 Watts. The power
\end{abstract}


requirement of 358 Watts could be supplied by a $100 \mathrm{Wp}$ solar panel, since the power released from a $100 \mathrm{Wp}$ solar panel is 400 Watts.

Keywords: automatic hand washing equipment, solar energy, input power, solar intensity

\section{Pendahuluan}

Daerah yang memiliki intensitas panas matahari yang tinggi sangat tepat untuk diterapkan energi listrik dari tenaga surya [1]. Energi surya adalah energi yang berupa panas dan cahaya yang dipancarkan matahari yang merupakan sumber energi terbarukan [2]. Tenaga surya meiliki beberapa keuntungan anatara lain energinya tersedia secara Cumacuma, dengan sistem perawatan yang mudah dan tidak ada komponen yang bergerak sehingga tidak menimbulkan suara atau kebisingan. Tenaga surya mampu bekerja secara otomatis, akan tetapi tenaga surya juga memliki kendala yaitu energi yang dihasilkan tergantung pada intensitas cahaya matahari yang tidak tersedia 24 jam sehari sehingga diperlukan suatu media penyimpanan energi berupa baterai sebagai sumber energi pada saat intensitas cahaya matahari menurun atau bahkan tidak ada sama seklai [3].

Energi surya merupakan energi yang tidak akan ada habis persediaanya, dan energi ini juga dapat dimanfaatkan sebagai energi alternatif yang dikoversi menjadi energi listrik melalui panel surya [4]. Inovasi pengembangan energi surya terus di lakukan seperti yang dilakukan oleh [5] mengembangkan energi surya sebagai suplai listrik untuk rumahan dengan sistem off-grid, kemudian [6] mengembangkan Energi surya sebagai suplai energi listrik untuk pompa air dimana listrik yang dihasilkan disimpan kedalam baterai dan dapat langsung digunakan untuk sumber listrik pompa air 60 watt yang bekerja selama 32 menit unutk 1.750 liter.

Kelayakan energi surya juga dimanfaatkan sebagai suplai energi listrik untuk alat pengering pupuk petani [7], penelitan lain terkait pemanfaatan energi surya juga dilakukan oleh [8] yang melakukan pembuatan pompa air betenega surya dimana energi surya 100 wp yang di konversi menjadi 1000 watt mampu mengoperasikan pompa untuk mengairi persawahan. Penelitian lain terkait energi surya yaitu pemanfaaan energi surya sebagai suplai energi listrik untuk kompor listrik, penelitian ini menggunakan 4 buah panel surya $120 \mathrm{wp}$ mampu menghasilkan voltase sebesar 19 Volt danarus sebesar 19,02 Ampere teknologi ini mampu mengoreng telor dengan waktu 4 meit [9].

Alat pemasak tenaga surya yang sehat dengan sistem terisolasi ini juga teknologi memasak yang aman dan sehat bagi perngguna, serta murah dalam pembuatannya [10]. Inovasi lain terkait pemenfaatan energi surya juga telah dilakukan seperti pemanfaatan energi surya sebagai basis untuk suplai energi listrik alat cuci tangan listrik otomatis. Teknologi ini dapat menghasilkan daya sebesar 113,95 Wh, konsumsi daya sebesar 17 watt durasi peakaian hingga 7 jam perhari [11]. Selanjutnya rancang bangun alat cuci tangan otomatis portable dengan teknologi mikrokontroler arduino uno, alat ini mengunakan panel surya dengan kapasitas $10 \mathrm{Wp}$ dan baterai $12 \mathrm{~V} / 5 \mathrm{Ah}$, dimana berdasarkan hasil pengujian menunjukan bahwa panel surya dan baterai tidak optimal untuk dapat menjalankan sistem alat cuci tangan otomatis tersebut [12]. Selanjutnya pembuatan alat tempat cuci tangan otomatis guna pencegahan penyebaran virus corona telah dilakukan dimana alat ini akan diaplikasikan di pasar Wongsorejo Kecamatan Wongsorejo [13]. Selanjutnya penelitian telah dilakukan oleh [14] tentang pembersih tangan otomatis dilengkapi air, sabun, hand dryer dan LCD menggunakan sensor infrared berbasis arduino dimana alat ini mampu beroperasi sesuai perancangan dengan pemanfaatan sensor yang berkerja sehingga air, sabun dan hand dryer mampu bekerja secara otomatis. Selanjutnya penelitian dilakukan oleh [15] tentang rancang bangun wastafel portabel otomatis bertenaga surya sebagai proteksi pencegahan covid 19, alat ini dapat beroperasi dengan baik dimana hasil pengujian menunjukan bahwa energi yang dihasilkan penel surya sebesar $17 \mathrm{~W}$ dan dapat beroperasi selama 6,7 jam perhari jika digunakan tanpa henti.

Penelitian yang akan dilakukan dalam tulisan ini adalah melakukan perancangan dan pengujian alat cuci tangan otomatis berbasis energi surya $100 \mathrm{wp}$, dengan melakukan pengamatan, dan pencatatan data-data yang dikeluarjkan oleh alat ukur yang ada pada panel surya.

Rangakaian pembangkit listrik tenaga surya meliputi panel surya, solar charge controler, baterai , inverter, ampere meter, dan volt meter.

\subsection{Panel surya}

Panel surya merupakan komponen yang dapat mengubah cahaya menjadi listrik, komponen ini memanfaatkan cahaya matahari sebagai sumbernya. Panel surya juga biasa disebut dengan sel photovoltaic, dimana panel surya dapat menhasilkan kluaran berupa tegangan atau arus listrik karena adanya hubungan atau kontak dua 
DOI: 10.35970/accurate.v2i1.580

elektroda saat panel surya mendapatkan cahaya matahari [15].

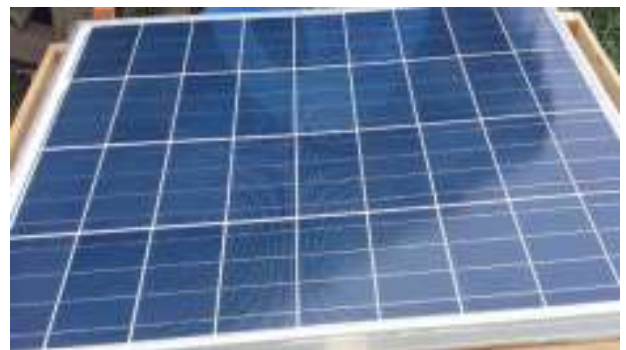

Gambar 1. Panel sel surya [16]

\subsection{Solar charge controler}

Solar charge controler merupakan peraltan yang berfungsi untuk mendeteksi kapan sel surya bermuatan penuh dan untuk menghentikan pengisian sebelum pengisian berlebih atau panas [17].

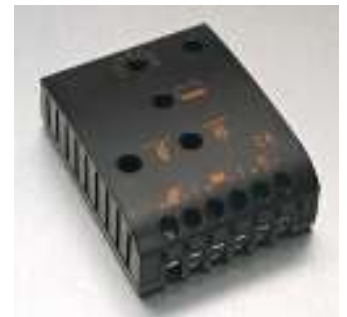

Gambar 2. Solar charge controler [18].

\subsection{Baterai}

Baterai merupakan alat listrik kimiawi yang menyimpan energi dan mengeluarkan tenaga dalam listrik. Baterai dalam PLTS digunakan sebagai komponen penyimpan energi listrik arus searah DC yang berasal dari panel surya [19].

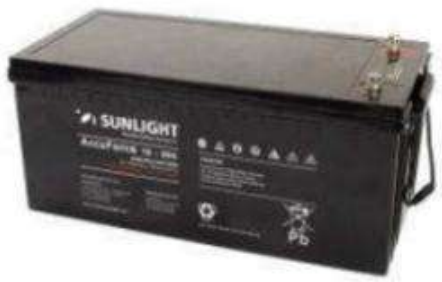

Gambar 3. Baterai [16]

\subsection{Inverter}

Inverter merupakan sebuah alat yang berfungsi untuk merubah arus DC menjadi arus AC [20].

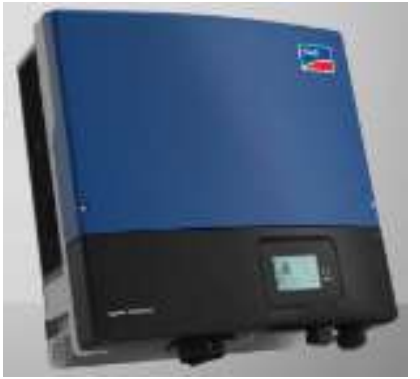

Gambar 4. Inverter [17]
e-ISSN 2722-5089 and p-ISSN: 2722-4279

\section{Metodologi Penelitian}

Metodologi penelitian diawali dengan perancangan, pebuatan sketsa, persiapan alat dan bahan, pembuatan dan pengujian. Metode dalam pembuatan alat menggunakan metode pahl and beitz dan metode yang digunakan dalam pengujian adalah metode eksperimen. Perancangan menurut metode pahl and beitz terdiri dari 4 tahap diantaranya:

1. Fase perumusan tugas

2. Fase fungsional

3. Fase bentuk desain

4. Fase hasil

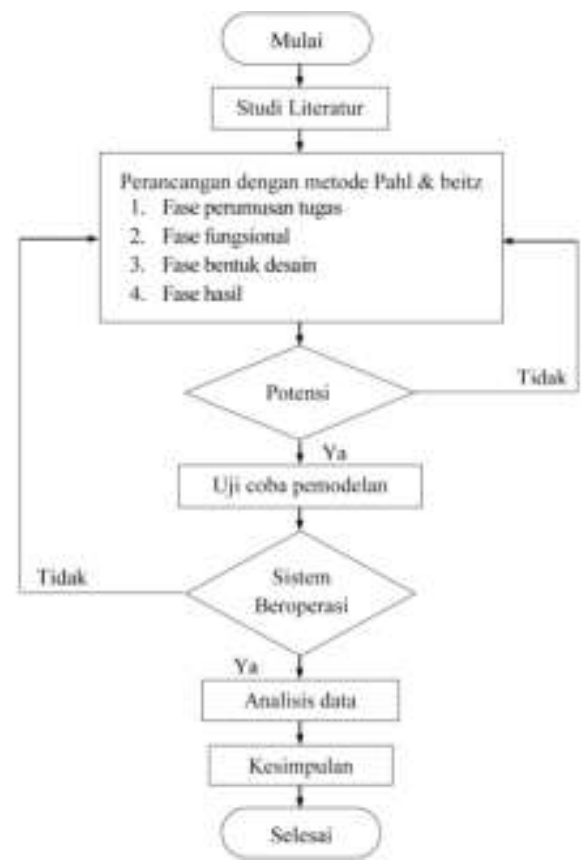

Gambar 5. Diagram alir penelitian

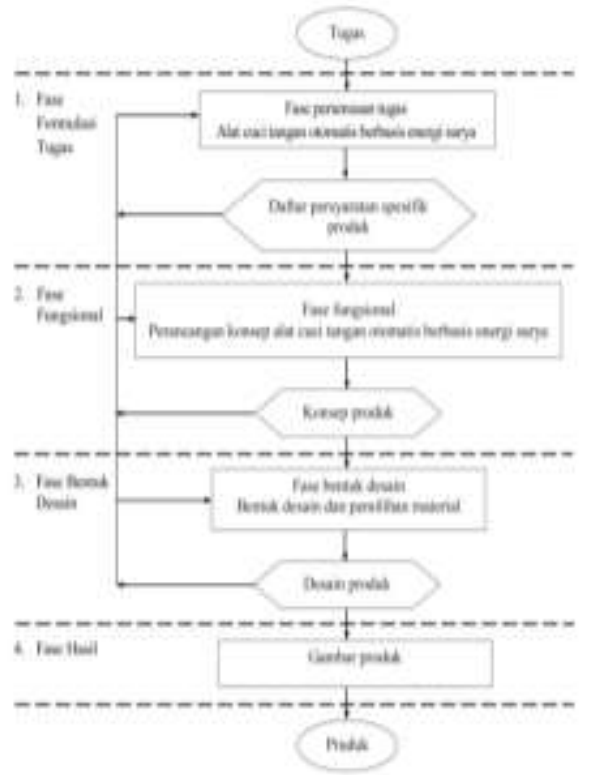

Gambar 6. Diagram alir proses perancangan Pahl dan Beitz 
DOI: 10.35970/accurate.v2i1.580

\subsection{Alat dan bahan uji yang digunakan}

Alat dan bahan yang diuji dapat dilihat pada tabel 1 berikut:

Tabel 1. Alat dan Bahan yang Diuji

\begin{tabular}{ccc}
\hline Alat uji & Bahan yang diuji & Spesifikasi \\
\hline $\begin{array}{c}\text { Solar power } \\
\text { meter }\end{array}$ & Modul surya & $100 \mathrm{WP}$ \\
$\begin{array}{c}\text { Termometer } \\
\text { digital }\end{array}$ & Suhu modul surya & $100 \mathrm{WP}$ \\
Multi meter & Tegangan modul & $100 \mathrm{WP}$ \\
digital & surya & $100 \mathrm{WP}$ \\
$\begin{array}{c}\text { Ampere meter } \\
\text { Volt meter }\end{array}$ & $\begin{array}{c}\text { Arus output modul } \\
\text { Tegangan pada } \\
\text { beban }\end{array}$ & - \\
\hline
\end{tabular}

\subsection{Bahan}

Berdasarkan metode yang digunakan dalam penelitian ini maka untuk pemilihan bahan yang digunakan diambil beberapa varian yang nantinya akan dipilih varian yang handal, murah, mudah perawatan, mudah perakitan dan pembuatan.

Tabel 2. Matriks Morfologi Bahan

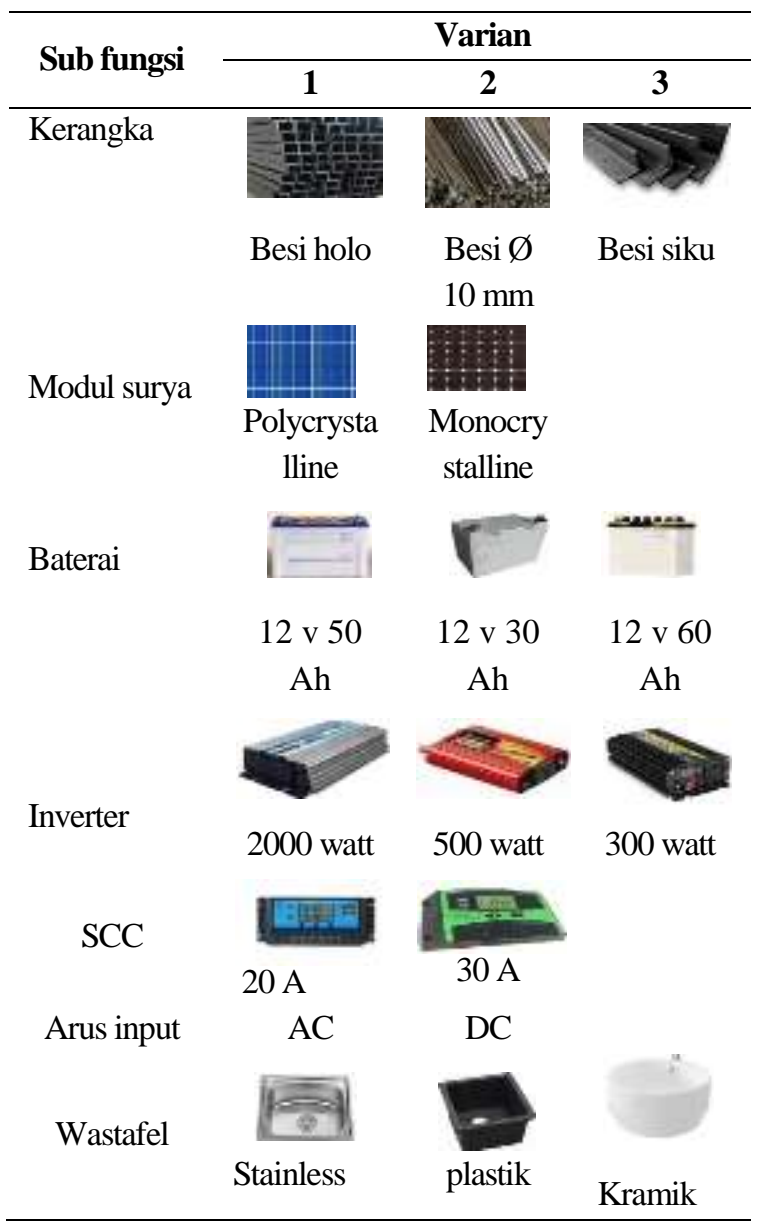

e-ISSN 2722-5089 and p-ISSN: 2722-4279

\subsection{Pengujian alat}

Pengujian dilakukan dengan tujuan untuk mengetahui keberhasilan alat untuk beroperasi, tahapan pengujian diawali dengan pengujian intensitas matahari, dan pengujian daya berdasarkan kebutuhan beban

\section{Hasil dan Pembahasan}

Sebelum melakukan pengujian maka perlu dilakukan perancangan dan pembuatan alat, tahapannya adalah sebagai beriut:

\subsection{Perhitungan kebutuhan beban}

Untuk menghitung beban energi yang digunakan dapat dilihat pada tabel 3 berikut:

Tabel 3. Kebutuhan Energi

\begin{tabular}{lcc}
\hline \multicolumn{1}{c}{ Jenis beban } & \multicolumn{2}{c}{ Waktu pengoperasian } \\
\cline { 2 - 3 } & Siang & Malam \\
\hline $\begin{array}{l}1 \text { buah kran air otomatis } \\
10 \text { watt } \\
\begin{array}{l}1 \text { buah pompa otomatis } 50 \\
\text { watt }\end{array}\end{array}$ & 5 jam & 1 jam \\
\hline
\end{tabular}

Maka pemakaian energi keseluruhan adalah $(1 \times 10 \times 6)+(1 \times 50 \times 6)=360$ watt. Untuk DoD (depth of charge) dalam baterai sebesar $20 \%$ [21]. $=20 \% \times 360$ $\mathrm{Wh}=72$ watt sehingga total energi yang dibutuhkan adalah sebesar 360 watt +72 watt $=432$ watt

\subsection{Perhitungan daya solar cell}

Dari analisis energi yang dibutuhkan maka modul surya harus mampu beroperasi sesuai kebutuhan energi tersebut, maka modul surya dipilih $100 \mathrm{wp}$ sehingga $100 \mathrm{wp}$ x 4 jam intensitas normal penyerapan modul surya, $100 \times 4=400$ Watt

\subsection{Perhitungan daya baterai}

Dari analisis energi yang dibutuhkan maka daya baterai harus lebih dari daya yang di butuhkan, daya yang butuhkan sebesar 432 watt maka baterai dipilih 12 volt $50 \mathrm{Ah}=600$ watt

\subsection{Inverter}

Inverter yang digunakan dalam penelitian ini menggunakan inverter dengan daya 500 watt. 
Tabel 4. Parameter Bahan Alat Cuci Tangan Otomatis

\begin{tabular}{llll}
\hline \multicolumn{1}{c}{ Parameter } & \multicolumn{1}{c}{ Spesifikasi } & Nilai & Satuan \\
\hline Modul & Polycrystalline & 100 & Wp \\
Kran air & otomatis & 30 & watt \\
Kran sabun & otomatis & 30 & watt \\
Baterai & 12 volt 50 Ah & 600 & watt \\
Inverter & DA5-315 & 500 & watt \\
\hline
\end{tabular}

\subsection{Perancangan alat cuci tangan otomatis berbasis energi surya menurut Pahl \& Beitz}

\section{Fase perumusan tugas}

Pada fase ini memilih peryaratan spesifik dari produk alat cuci tangan yang akan dibuat. Adapun persyaratan spesifik dari alat cuci tangan otomatis berbsis energi surya adalah sebagai berikut:

a. Kerangaka panel surya dan wastafel

Untuk kerangaka yang dipilih harus kokoh dan tidak mudah penyok karena benturan benda keras.

b. Modul surya

Untuk modul surya yang dipilih harus dapat menerima dan menyerap intensitas matahari ketika kondisi cerah maupun berawan.

c. Baterai

Untuk baterai yang dipilih harus tahan dan dapat menyimpan daya yang sesuai kebutuhan alat cuci tangan otomatis tersebut.

d. Inverter

Untuk inverter yang dipilih harus disesuaikan dengan besaran daya yang akan dioperasikan.

e. Solar charge controller

Untuk SCC yang dipilih disesuaikan dengan besar wattpeak pada modul surya

f. Wastafel

Untuk wastafel yang dipilih harus kokoh, tidak mudah penyok, tahan karat dan mudah dalam perawatannya.

2. Fase fungsional

Pada fase ini adalah fase menentukan konsep produk, produk akan digambar dan diskets menggunkan software AutoCAD 2010

3. Fase bentuk desain

Pada fase ini adalah fase bentuk desain dan pemilihan material, yang diawali dari:

a. Pembutaan rangka untuk dudukan panel surya dan wastafel yang diawalai dari pemotongan menggunakan mesin gerinda dan pengelasan menggunakan las listrik

b. Selanjutanya adalah proses pengecatan kerangaka c. Setelah cat kering dilanjutkan dengan perakitan modul surya, SCC, inverter, baterai, wastafel, sensor, pompa, dam keran.

Untuk pemilihan material sesuai dengan tabel 2 . Matriks morfologi bahan maka:

a. Modul menggunakan varian 1, mampu menyerap intensitas matahari dalam keadaan berawan

b. SCC menggunakan varian 1, spesifikasi untuk 100 wp

c. Inverter menggunakan varian 2 , untuk daya dibawah 500 watt

d. Baterai menggunakan varian 1 , tahan dan sesuai kebutuhan beban beroperasi 8 jam

e. Wastafel menggunakan varian 1 , tahan karat dan mudah perawatan

f. Kerangka menggunakan varian 1, minimalis, mudah didesain, ringan dan kokoh

4. Fase hasil

Pada fase ini adalah fase perancangan detail produk dan gambar desain produk, adapun tahapannya adalah sebagai berikut:

a. Ukuran tinggi kerangak modul sebesar $100 \mathrm{~cm}$

b. Ukuran lebar dudukan modul $100 \mathrm{~cm}$ x $78 \mathrm{~cm}$

c. Ukuran alas kerangaka $100 \mathrm{~cm}$ x $80 \mathrm{~cm}$

d. Ukuran dudukan SCC, dan Inverter $80 \mathrm{~cm}$ x $40 \mathrm{~cm}$

e. Ukuran dudukan wastafel dimana tinggi $90 \mathrm{~cm}$, lebar 45 $\mathrm{cm}$, dan panjang $55 \mathrm{~cm}$

Untuk gambar skets produk akan digambar menggunakan software AutoCAD 2010, sketsnya adalah sebagai berikut:
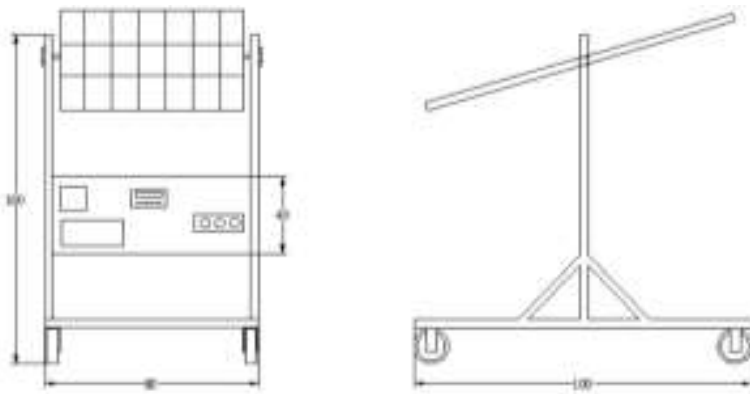

Gambar 7. Desain kerangka dan dudukan panel surya 

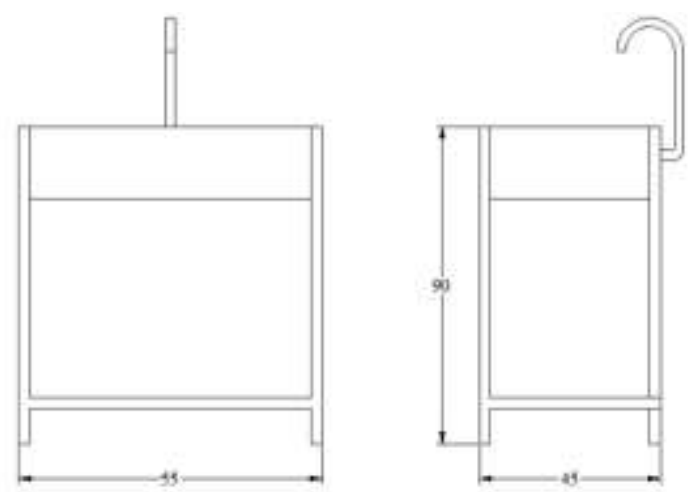

Gambar 8. Desain kerangka wastafel

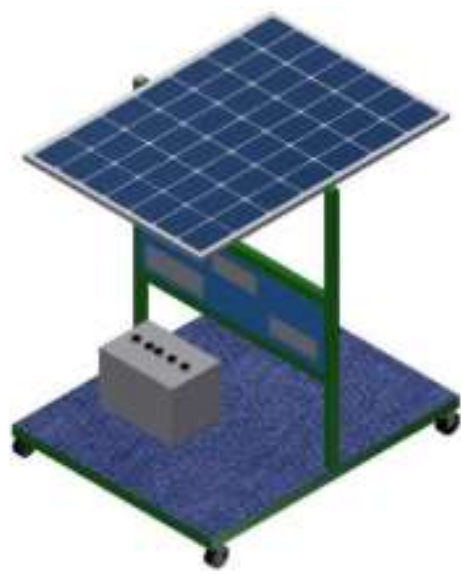

Gambar 9. Layout panel surya

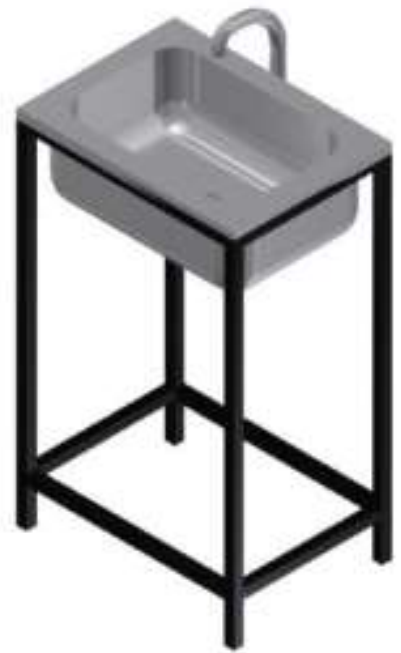

Gambar 10. Layout wastafel

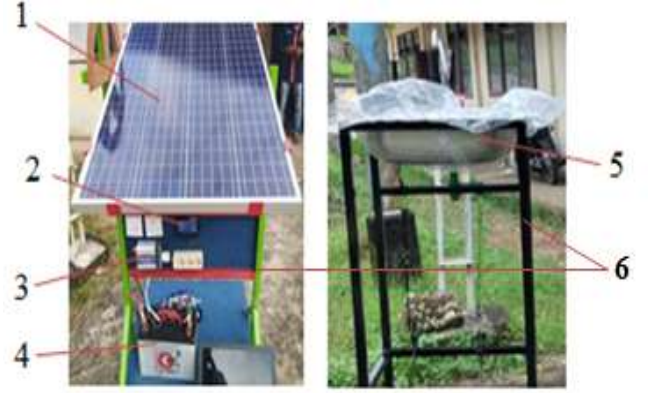

Gambar 11. Rangkaian panel surya 100 wp dan wastafel

Tabel 5. Komponen realisasi alat

\begin{tabular}{llc}
\hline No & \multicolumn{1}{c}{ Parameter } & Bahan \\
\hline 1 & Modul & Polycrystalline $100 \mathrm{Wp}$ \\
2 & SCC & $20 \mathrm{~A}$ \\
3 & Inverter & $500 \mathrm{watt}$ \\
4 & Baterai & 12 volt $50 \mathrm{Ah}$ \\
5 & wastafel & Stainless \\
6 & Kerangka & Besi hollow 25 mm x 25 \\
& & mm x 1.2 $\mathrm{mm}$ \\
\hline
\end{tabular}

\section{Proses pengujian}

Proses pengujian dilakukan untuk mengetahui kesesuaian alat dapat beroperasi, jika dalam pengujian ditemukan ketidak sesuaian maka akan dilakukan perancangan dan pebuatan ulang. Pengujian dilakukan 3 tahapan, yang pertama pengujian daya input modul surya $100 \mathrm{wp}$, pengujian lama pengisian baterai, pengujian daya sensor pompa air otomatis.

\subsection{Pengujian daya input modul solar cell}

Pengujian daya input solar cell dilakukan pada sudut $0^{\circ}$. Untuk mengetahui hasil pengujian dapat dilihat pada tabel 6 berikut:

Tabel 6. Pengujian modul surya

\begin{tabular}{llllll}
\hline $\begin{array}{l}\text { Pukul } \\
(\mathbf{W I B})\end{array}$ & Cuaca & $\begin{array}{c}\mathbf{T} \\
\left(\mathbf{C}^{\circ}\right)\end{array}$ & $\begin{array}{c}\mathbf{A} \\
\left(\mathbf{m}^{\mathbf{2}}\right)\end{array}$ & $\begin{array}{c}\mathbf{G} \\
\left(\mathbf{W} / \mathbf{m}^{2}\right)\end{array}$ & $\begin{array}{l}\mathbf{P} \text { in } \\
(\text { watt })\end{array}$ \\
\hline 09.00 & Cerah & 48 & 0.76 & 1314 & 998,41 \\
10.00 & Cerah & 49 & 0,76 & 3049 & 2317,5 \\
11.00 & Cerah & 47 & 0,76 & 352 & 2680,6 \\
12.00 & Cerah & 44 & 0,76 & 4006 & 3044,5 \\
13.00 & Cerah & 45 & 0,76 & 4535 & 3446,2 \\
14.00 & Cerah & 59 & 0,76 & 3717 & 2824,5 \\
15.00 & Cerah & 37 & 0,76 & 2515 & 1911,5 \\
Total & & $\mathbf{3 2 7}$ & $\mathbf{0 , 7 6}$ & $\mathbf{2 2 . 6 6 2}$ & $\mathbf{1 7 . 2 2 3}$ \\
Rata-rata & $\mathbf{4 7}$ & $\mathbf{0 , 7 6}$ & $\mathbf{3 2 3 7}$ & $\mathbf{2 4 6 1}$ \\
\hline
\end{tabular}




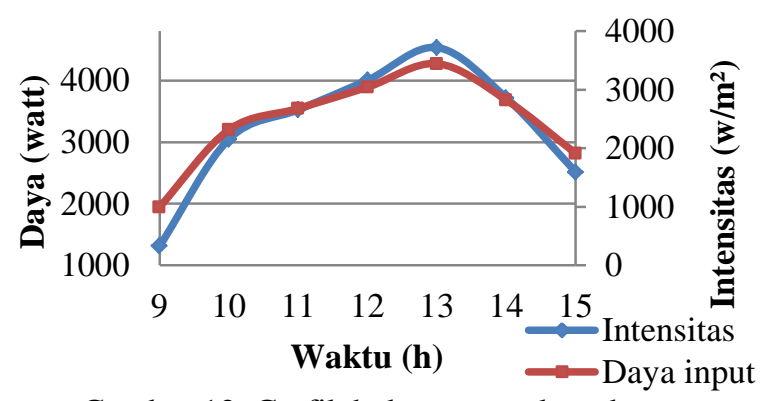

Gambar 12. Grafik hubungan waktu, daya, dan intensitas

Pada gambar 12 menunjukan trend meningkat kemudian menurun, peningkatan trend ditunjukkan pada pukul 13.00 WIB kemudian menurun hingga pukul 15.00 WIB, penyebab peningkatan trend akan diikuti oleh peningkatan intensitas cahaya matahari yang diserap oleh modul surya dan sebaliknya penurunan juga dipengaruhi oleh intensitas matahari yang telah menurun. Daya puncak pada pengujian ini ditunjukkan pada pukul 13.00 WIB.

\subsection{Pengujian lama pengisian baterai}

Lama waktu pengisian baterai adalah besarnya arus yang masuk kedalam baterai hal ini selalu dipengaruhi dengan besar intensitas yang diserap matahari per jam. Lama waktu pengisian baterai adalah kapasitas baterai dibagi dengan arus output charger $=$ $50 \mathrm{Ah}: 20 \mathrm{~A}=2,5$ jam diuji pada intensitas matahari tertinggi.

\subsection{Pengujian sensor pompa otomatis}

Pengujian energi surya untuk alat cuci tangan otomatis pada pengujian adalah sesuai karena untuk mengoperasikan teknologi dengan kebutuhan daya 432 watt masih tercukupi dengan hasil output energi listrik surya sebesar 600 watt DC yang dikonversi melalui inverter sebesar 500 watt AC.

\section{Kesimpulan}

Perancangan dan pengujian cuci tangan otomatis berbasis energi surya $100 \mathrm{wp}$ telah dilakukan dan telah dibuat dalam bentuk purwarupa. Hasil perancangan alat cuci tangan otomatis dengan menggunakan metode pahl and beitz menunjukan hasil yang kuat dan kokoh, ringan, tidak mudah korosi karena wastafel dipilih dari bahan tahan korosi, dimana untuk modul surya dipilih jenis polycristalyne. Alat ini juga mudah dalam perawatan dan mudah untuk dipindahkan karna didesain dengan konsep portabel dengan spesifikasi untuk kerangka modul surya tinggi $100 \mathrm{~cm}$ lebar $80 \mathrm{~cm}$ sedangkan untuk kerangka watafel sebesar tinggi $90 \mathrm{~cm}$ lebar $45 \mathrm{~cm}$ dan panjang 55 $\mathrm{cm}$. Pengujian dilakukan dengan 3 tahapan, tahap pertama dilakukan pengujian pada daya input modul, daya input modul pada pengujian menghasilkan daya sebesar 2461 watt dengan intensitas radiasi matahari sebesar $3237 \mathrm{~W} / \mathrm{m}^{2}$. Puncak intensitas dan daya matahari ditunjukan pada pukul 13.00 WIB, pengujian ke dua untuk lama waktu pengisian baterai membutuhkan waktu 2,5 jam, penguian ketiga ini yaitu kebutuhan daya sensor dan pompa sebesar 358 watt. Kebutuhan daya sebesar 358 watt dapat di suplai oleh panel surya kapasitas $100 \mathrm{wp}$, karena daya yang dikeluarkan dari panel surya $100 \mathrm{wp}$ sebesar 400 watt.

\section{Daftar Pustaka}

[1] O. Jaelani and H. Suripto, "Analisis Performa dan Nilai Ekonomi Sistem Solar Cell Untuk Pengoperasian Pompa Air dengan Metode Eksperimental," J. Rekayasa Mesin, vol. 15, no. 1, p. 42, 2020, doi: 10.32497/jrm.v15i1.1742.

[2] W. Rosida, "Konsep Rumah Scandinavian," vol. 1, no. 1, pp. 4-8, 2017, [Online]. Available: https://www.arsitag.com/article/bagaimana-caramembangun-rumah-dengan-konsepscandinavian.

[3] M. Irwansyah, D. Istardi, and N. Batam, "Pompa Air Aquarium Menggunakan Solar Panel," vol. 5, no. 1, pp. 85-90, 2013.

[4] B. H. Purwoto, "Efisiensi Penggunaan Panel Surya Sebagai Sumber Energi Alternatif," Emit. J. Tek. Elektro, vol. 18, no. 01, pp. 10-14, 2018, doi: 10.23917/emitor.v18i01.6251.

[5] O. M. Roche and R. E. Blanchard, "Design of a solar energy centre for providing lighting and income-generating activities for off-grid rural communities in Kenya," Renew. Energy, vol. 118, pp. 685-694, 2018, doi: 10.1016/j.renene.2017.11.053.

[6] Z. Iqtimal and I. Devi, "Aplikasi Sistem Tenaga Surya Sebagai Sumber Tenaga Listrik Pompa Air," J. Komputer, Inf. Teknol. dan Elektro, vol. 3, no. 1, pp. 1-8, 2018.

[7] S. Aryza, H. Hermansyah, A. P. U. Siahaan, S. Suherman, and Z. Lubis, "Implementasi Energi Surya Sebagai Sumber Suplai Alat Pengering Pupuk Petani Portabel," It J. Res. Dev., vol. 2, no. 1, pp. 12-18, 2017, doi: 10.25299/itjrd.2017.vol2(1).642. 
DOI: 10.35970/accurate.v2i1.580

[8] A. L. Rettob and R. S. Waremra, "Pompa Air Bertenaga Energi Matahari (Solar Cell) Untuk Pengairan Sawah," Musamus J. Sci. Educ., vol. 1, no. 2, pp. 046-052, 2019, doi: 10.35724/mjose.v1i2.1451.

[9] H. Asyari and U. Umar, "Desain Prototipe Kompor Listrik Tenaga Surya," Emit. J. Tek. Elektro, vol. 19, no. 1, pp. 6-9, 2019, doi: 10.23917/emitor.v19i1.6997.

[10] T. Watkins et al., "Insulated Solar Electric Cooking - Tomorrow's healthy affordable stoves?," Dev. Eng., vol. 2, no. September 2016, pp. 47-52, 2017, doi: 10.1016/j.deveng.2017.01.001.

[11] M. Asis, N. Arsyad, and Studi, "RANCANG BANGUN WASTAFEL PORTABEL OTOMATIS BERTENAGA SURYA," vol. 3, no. September, pp. 78-87, 2015, doi: 10.31962/jiitr.v3i2.52.

[12] R. Febriansyach, D. B. Santoso, U. Latifa, and S. Karawang, "Portable Dengan Teknologi Mikrokontroler Arduino Uno Design of Portable Automatic Hand Washer With," vol. 6, no. 2, 2020.

[13] E. S. H. Lintar Anugerah Putra Yusya, Azizun Hakim, "'Smart Wijik' Pembuatan Alat Tempat Cuci Tangan Otomatis Guna Pencegahan Penyebaran Virus Corona Di Pasar Wongsorejo Kecamatan Wongsorejo," vol. 6, no. 3, pp. 129136, 2020.
e-ISSN 2722-5089 and p-ISSN: 2722-4279

[14] H. Hendri, "Pembersih Tangan Otomatis Dilengkapi Air, Sabun, Handdryer Dan Lcd Menggunakan Sensor Infrared Berbasis Arduino," J. Teknol., vol. 8, no. 1, pp. 1-14, 2018.

[15] S. Tesar Gantara Suherman, "Rancang Bangun Kompor Panel Surya," vol. 7, no. 1, 2018.

[16] L. Otong, J., As Natio, "Optimasi Perancangan Sistem Solar Cell Sebagai Sumber Energi Untuk Penggerak Pompa Air Di Daerah Pertanian Desa Karangsari Kecamatan," J. Ilm. TEKNOBIZ, vol. 8, no. 1, pp. 1-6, 2018.

[17] R. Karim, M. R. Islam, and N. Alam, "Installation of Solar PV System as an Alternate Source of Electric Stove and Gas Stove," pp. 111, 2015.

[18] H. Hasan, "Perancangan Pembangkit Listrik Tenaga Surya," J. Ris. dan Teknol. Kelaut., vol. 10, pp. 169-180, 2012.

[19] S. Teknika et al., "PERANCANGAN PEMBANGKIT LISTRIK TENAGA SURYA $100 \mathrm{Wp}$ UNTUK PENERANGAN LAMPU DI RUANG SELASAR,” vol. 3, no. 2, pp. 96-106, 2020.

[20] C. R. S.G., Ramadhan, "Perencanaan Pembangkit Listrik Tenaga Surya Di Atap Gedung Harry Hartanto Universitas Trisakti," Univ. Trisakti, pp. 1-11, 2017.

[21] R. T. Jurnal, "Studi Penyimpanan Energi Pada Baterai Plts," Energi \& Kelistrikan, vol. 9, no. 2, pp. 120-125, 2018, doi: 10.33322/energi.v9i2.48. 